\title{
A Call for a More Efficient Submission Process
}

\author{
Hans Oh
}

Suzanne Dworak Peck School of Social Work, University of Southern California, Los Angeles, CA 3551, USA; hansoh@usc.edu

Received: 13 July 2020; Accepted: 29 July 2020; Published: 30 July 2020

check for updates

\begin{abstract}
This commentary argues that the manuscript submission process is needlessly complicated and bothersome and would benefit from user experience research to simplify the author guidelines and to add design features that minimize mistakes.
\end{abstract}

Keywords: manuscript submission; user experience; design

A recent study examined the submission requirements of several scientific journals and found that around 9 out of 10 surveyed authors who published in these journals were dissatisfied with the manuscript submission process, favoring an overhaul of the entire submission system [1]. Much of the dissatisfaction comes from the varying submission requirements across journals [2-4] and the amount of time and energy that it takes to submit and resubmit manuscripts. In the year 2020, with advancements in technologies, it is hard to fathom why the scientific community has yet to find a better way.

In 2007, Stephen Welch [5] addressed common pitfalls of submitting manuscripts to the medical journal, Chest, stating:

"It is always baffling to think that authors fail to submit an abstract or title page of their manuscript, yet this commonly happens. Title pages are necessary within the manuscript itself to ensure the correct title, authors, author affiliations, and other key meta data are present."

At that time, title pages may still have been useful in publishing. However, over a decade later, it seems baffling now that journals would still require title pages and even more absurd that an incorrect title page would hold up a submission. I find that by the time I figure out what goes into the title page, I am left wondering why I have just gone through the tedious act of manually entering the title and author information directly into the submission site. Surely a title page can easily be generated automatically based on all the information I entered.

This line of questioning-where does this or that requirement belong, and why is it even necessary in the first place?-haunts every step of the submission process. Yet any deviation from the author guidelines will result in the manuscript being sent back [5]. If the journal administrators are merciful, they will simply 'unsubmit' the manuscript and demand the necessary changes. The unsympathetic administrators will reject the manuscript entirely, forcing the submission process to start again from the beginning.

To address the tremendous amount of time that researchers waste (re)formatting their manuscripts, an incipient movement is afoot to standardize (and hopefully simplify) submission requirements across journals [6]. However, it remains to be seen whether this movement is gaining any traction. Alternatively, centralized websites can be created that serve multiple journals, allowing for swift resubmissions from one journal to the next [7]. It is too early to tell if journals are willing to sign on to this idea; however, the Manuscript Exchange Common Approach initiative (approved by the National Information Standards Organization) has been endeavoring to facilitate transfers across manuscript submission systems, publishers, and pre-print servers. Maybe the most obvious way to save time is for 
all journals to agree to adopt a universal format-free initial submission policy and accept manuscripts in any style [1-4]. However, it seems that relatively few journals are on board with the idea [1].

Until any of these efforts are realized, there is still much that we can do to improve the existing system. User experience research can identify the most common errors that researchers make while submitting manuscripts. Design features-even minor modifications such as a well-placed check box or radio button - can minimize mistakes. Then, authors may not even have to review the detailed author guidelines to figure out, for example, where the conflict of interest statement belongs, since authors can simply check a box and if necessary enter this information into a dialogue box. Drag and drop features can make uploading files easier and can be configured to order the files automatically. Information can even be extracted directly from these files to auto-populate required metadata, though this requires some troubleshooting [8]. Cross-check reports can prevent submission of manuscripts that have significant overlap with other published articles or web content $[9,10]$. Without having to deal with all the mistakes, journal administrators and editors can focus on sending out the manuscripts to the right reviewers.

The submission process in its current state is tortuous, but we endure it quietly, perhaps because we feel like we are being a nuisance if we complain or believe that our patience will reap a favorable decision. However, consider how many researchers there are in the world and how many of our submitted manuscripts are sent back to us; the aggregated cost of wasted time and effort conservatively runs in the billions every year [2,11]. Jiang and colleagues argue that the effort to comply with submission requirements imposes a tremendous global economic burden when accounting for a researcher's time and energy, but their calculations do not factor in the enormous societal costs of delaying publications by weeks and even by months [1]. Imagine if a paper describing an important discovery in the midst of the COVID-19 pandemic were to be delayed by a few days or weeks, simply because the abstract was misplaced and sent back to the author (despite the abstract being copy-and-pasted directly into a free-response field in the submission portal). Delays in publishing could have profound consequences [12].

Rejection rates are high for the top journals [11], but rejection is an important part of the scientific process and likely improves the impact of an article in the long run [13]. However, we do not have a submission process that can accommodate the rate of rejection and resubmission. Rigorous peer review and dissemination of scientific findings already lags [14], and most researchers are in support of a more streamlined process. So, let us remove as many barriers as we can and fight for hassle-free submission processes.

Funding: This research received no external funding.

Acknowledgments: The author would like to thank Gina Yang.

Conflicts of Interest: The author declares no conflict of interest.

\section{References}

1. Jiang, Y.; Lerrigo, R.; Ullah, A.; Alagappan, M.; Asch, S.M.; Goodman, S.N.; Sinha, S.R. The high resource impact of reformatting requirements for scientific papers. PLoS ONE 2019, 14, e0223976. [CrossRef] [PubMed]

2. Budd, J. Reformatting wastes public funds. Nature 2017, 543, 40. [CrossRef] [PubMed]

3. Guo, Q. Journals, agree on manuscript format. Nature 2016, 540, 525. [CrossRef] [PubMed]

4. Moore, J.P. Journals, do your own formatting. Nature 2017, 542, 31. [CrossRef] [PubMed]

5. Welch, S.J. Avoiding common problems during online submission of manuscripts. Chest 2007, 131, 1591-1594. [CrossRef] [PubMed]

6. Ufnalska, S.; Terry, A. Proposed universal framework for more user-friendly author instructions. Eur. Sci. Ed. 2020, 46, e53477. [CrossRef]

7. Birkhead, T.; Montgomerie, R. The Frustrating Process of Manuscript Submission. The Scientist, 10 May 2017.

8. Chou, K.-C. The Problem of Elsevier Series Journals Online Submission by Using Artificial Intelligence. Nat. Sci. 2020, 12, 37-38. [CrossRef] 
9. Zhang, H. CrossCheck: An effective tool for detecting plagiarism. Learn. Publ. 2010, 23, 9-14. [CrossRef]

10. Zhang, Y.; Jia, X. A survey on the use of CrossCheck for detecting plagiarism in journal articles. Learn. Publ. 2012, 25, 292-307. [CrossRef]

11. Khan, A.; Montenegro-Montero, A.; Mathelier, A. Put science first and formatting later. EMBO Rep. 2018, 19, e45731. [CrossRef] [PubMed]

12. Pei, S.; Kandula, S.; Shaman, J. Differential Effects of Intervention Timing on COVID-19 Spread in the United States. medRxiv 2020. [CrossRef]

13. Ball, P. Rejection improves eventual impact of manuscripts. Nature 2012. [CrossRef]

14. Powell, K. Does it take too long to publish research? Nat. News 2016, 530, 148. [CrossRef] [PubMed]

(C) 2020 by the author. Licensee MDPI, Basel, Switzerland. This article is an open access article distributed under the terms and conditions of the Creative Commons Attribution (CC BY) license (http://creativecommons.org/licenses/by/4.0/). 